\title{
A renewed framework for urban biodiversity governance: urban pigeons as a case-study
}

\author{
Zina Skandrani ${ }^{1, *}$, Marion Desquilbet ${ }^{2}$ and Anne-Caroline Prévot ${ }^{1}$ \\ 1 Ecology, MNHN, UMR7204 Cesco, Paris, France \\ ${ }^{2}$ Economy, Inra, UMR5314 TSE-Recherche, Toulouse, France
}

Received 22 November 2016. Accepted 5 December 2017

Cet article, issu d'un double regard d'écologues et d'économiste, nous rappelle que la gouvernance environnementale ne peut se limiter à la mise en application de quelques principes écologiques mais reste à construire par une approche socioécologique de chaque situation. Traitant du cas du pigeon urbain, les auteurs montrent comment se pose la problématique de la gouvernance de la biodiversité urbaine lorsque cette nature, perçue d'abord comme nuisible, est source de conflits sociaux au sein de la cité. Pour sortir de cette impasse, les auteurs proposent un cadre de gouvernance dite intégrée prenant en charge, non plus le contrôle des éléments de nature, mais la mise en relation des humains et de ces éléments dans une démarche inclusive, redéfinissant ainsi le rôle des autorités locales et de leurs politiques en termes d'aménagement et de communication.

La Rédaction

\begin{abstract}
In a globally urbanizing world, interactions between individuals and nature are progressively decreasing. In this context, it is not uncommon that the presence of some remaining animal species in cities causes problems to urban citizens and results in conflicts among stakeholders. Here, we propose a novel vision of the relations between urban citizens, local authorities and urban nature, taking the example of urban pigeons. We combined ecological and sociological concepts as well as data to propose a new working framework to build an integrative governance of urban nature. We showed how effective it is to change the focus on elements of nature only by including the interrelations between humans and nature. We highlighted the importance of institutional messages when dealing with biodiversity issues. We conclude by calling for a holistic vision in the implementation of policy on urban nature.
\end{abstract}

Keywords: city / governance / urban pigeons / socioecological systems / public policies

Résumé - Vers une nouvelle gouvernance de la biodiversité urbaine ? Le cas du pigeon urbain. Dans notre monde de plus en plus urbanisé, les interactions des individus avec la nature et ses éléments deviennent de moins en moins fréquentes. Dans ce contexte, il n'est pas inhabituel que la présence de certaines espèces encore présentes en ville puisse poser des problèmes aux citadins et soit une source de conflit entre différents acteurs urbains. Nous proposons ici un nouveau regard sur les relations entre citadins, autorités locales et la nature urbaine, en prenant les pigeons urbains comme exemple. Nous avons intégré des principes écologiques et des concepts sociologiques de même que des données empiriques afin de proposer un nouveau cadre opérationnel pour une gouvernance intégrative de la nature urbaine. Nous avons mis en évidence comment le fait d'ouvrir une approche focalisée uniquement sur les éléments naturels dans l'analyse des conflits pour y inclure les interrelations entre humains et nature peut s'avérer porteur de solutions et de pistes de réflexion nouvelles. Nous soulignons enfin l'importance de la communication et des messages institutionnels dans les problématiques publiques liées à la biodiversité et nous concluons par un appel à une vision holistique dans la mise en œuvre de politiques publiques sur la nature urbaine.

Mots-clés : ville / gouvernance / pigeon urbain / systèmes socioécologiques / politiques publiques 
In addition to ecological issues, the loss of the sense of interrelations is suggested by some authors as a main dimension of the current biodiversity crisis, be it interdependence with nature and biodiversity or interrelations with other humans (Koger and Winter, 2010) ${ }^{1}$. Ever-increasing urbanization and the modern western way of life (McKinney, 2002; Rosenzweig, 2003) often discourage direct contact with nature and biodiversity (Soga and Gaston, 2016; Miller, 2005; Louv, 2008), as well as between humans (Dunn et al., 2006). Yet while urban biodiversity is far less abundant and diverse than in more natural habitats (McKinney, 2002), some animal species have adapted particularly well to the proximity of humans by exploiting their resources (McKinney, 2002; Møller, 2008). However, the presence of these species is sometimes a source of conflicts with urban citizens, as for instance rabbits, foxes, seagulls, rats, coyotes, deer, cougars or geese (Kalof and Amthor, 2010). Rather than helping to connect humans with nature, the presence of these species in the cities may at times generate social conflicts (Fall and Jackson, 2002; Gouabault and BurtonJeangros, 2010). Finding a way for coexistence between humans and fauna in cities remains therefore a major challenge.

In urban environments, many authors have recently underlined the importance of considering ecological and social systems together, as socioecological ecosystems, rather than independently (Pickett et al., 2008). By doing so, these authors integrate in an original way reciprocal influences and dynamics among social, political/institutional, and ecological variables (Ostrom, 2009). In line with environmental pragmatism (Minteer and Collins, 2005), adjustive management (Maris and Béchet, 2010) and other approaches (Buijs and Elands, 2013), these frameworks can help resolve socioecological conflicts by clarifying the underlying social representations at stake and how they come about. They can notably help analyze critically the discourses shaping their articulation (Moscovici, 2000) and the related communication processes in multiple social interactions, in relation to knowledge, education, and the social groups to which people belong, but also to the ecology of the involved species, and to public policies (Mugerauer, 2010;

\footnotetext{
${ }^{1}$ The considerations presented here are derived from Zina Skandrani's doctoral work in which the author proposed a novel governance system for urban biodiversity based on an indepth study of the place of urban pigeons in urban public spaces. Her thesis was defended on September 15, 2014 at the Muséum national d'Histoire naturelle. This study is based on data and insights gained through a multi-year research-action program on urban pigeons run by the French national museum of natural history (MNHN) and other scientific and nonscientific partners (subsequently referred to as the "MNHN pigeon program").
}

Robbins, 2007; Moscovici, 2000). Exploring the processes underlying the socioecological conflicts involves therefore considering all members of society and concerned stakeholders as well as their interactive dynamics and reciprocal influences (Gobster et al., 2007), through which meaning is assigned to the environment (Mugerauer, 2010). Moreover, both human and non-humans are enrolled and hold agency in this meaning production (actor network theory, Latour, 1993). Thus, in addition to lay people and institutions, plant and animal species must be integrated as essential actors, or "actants" (Latour, 1993), of the socioecological system.

One famous example of this difficult cohabitation concerns the presence of feral pigeons, Columba livia, in cities. Feral urban pigeons, descended from the domesticated rock doves that were bred all around the world, are currently present in most large cities throughout the world, after their abundance increased in the first part of the $20^{\text {th }}$ century (Hoyo et al., 2005; Johnston and Janiga, 1995). Urban pigeons are commonly depicted as "pests" and have led to continuous institutional efforts to control their abundance (Haag-Wackernagel, 2002). Urban pigeons are mostly credited with a highly negative image in the mainstream public opinion (Vuorisalo et al., 2001) and are typically objects of complaints in most major Western cities since the mid- $20^{\text {th }}$ century. The most frequent complaints relate to viruses and diseases of pigeons, because of which pigeons are viewed as a threat to humans, "rats with wings" (Jerolmack, 2008). When animals colonize new niches by adapting to and settling in places different from their original ecosystems, they may present a visible contradiction to human definitions of these landscapes and their assigned species. In particular, cities are subject to an ordering process that clearly determines what can be included and what does not belong to it (Griffiths and Poulter, 2000). In such cases, species disturbing defined spatial relations that underlie human qualifications of biodiversity may become labeled as dirty and "nuisance" species (Jerolmack, 2008; Philo and Wilbert, 2000). These concepts revive the founding myths of Western societies, from the Plagues of Egypt to the Odyssey or the Pied Piper of Hamelin, revealing the inherent fears and unease raised by this disorder (Claeys and Sirost, 2010).

From this perspective, the narratives of pigeons as well as of other species such as cockroaches as pests (Mathieu et al., 1997) mobilize discourses about the nature-society/rural-urban dichotomy and the utilitarian understanding of animals. They may also reveal issues of human identity definition and projections of social relations that are at stake, as we highlighted elsewhere regarding the construction of pigeons as a nuisance species (Skandrani et al., 2014), or as reported regarding the projection of social discomfort towards strangers in 
the representation of cockroaches and their proliferation (Rivault et al., 1993).

Throughout history, however, pigeons have taken on important symbolic and functional roles, so that the dislike for pigeons is relatively new compared to their history of coexistence with humans (Skandrani et al., 2014). As a consequence of their central significance to humans for thousands of years, pigeons have retained a portion of their status as a peace symbol (e.g., the logo of the United Nations, Picasso's famous painting for the 1949 World Peace Congress, pigeon releases by the Pope or at weddings, etc.), and they still have active supporters among urban dwellers (Colon and Lequarré, 2013). Urban pigeons are thus among the few species that may cause social conflicts (Jerolmack, 2008), given that individuals have very strong stances for or against them (Colon and Lequarré, 2013; Skandrani et al., 2014). They are thus a good model to illustrate the high levels of complexity and uncertainty that often characterize socioenvironmental conflicts.

Environmental governance relevant to such conflictive issues needs to recognize and address this uncertainty and complexity (Corral and Acosta, 2017). Here, we understand environmental governance as the system of public policies and rules relative to the environment. It includes in particular the relationships between governance instruments, as well as with the different actors involved (Visseren-Hamakers, 2015). Based on this definition, we adopted an integrative perspective to consider the "pigeon problem", in which we assessed the combined ecological and social performances of interrelated multiple policies devoted to this issue.

A major challenge today is to develop governance models that resolve socioenvironmental conflicts in a fashion that secures a systems' capacity to support appeased social-ecological relationships into the future and to manage transitions toward new, more desirable configurations such as socioecological convivence. We propose a novel framework whose main goal is the reduction of social discomfort (Serpell, 2004) and therefore consider the challenge of humanpigeon coexistence beyond pigeon population control, by concentrating on social perceptions of the pigeons. We finally discuss the opportunities of these reconsiderations for a novel governance of urban nature, by illustrating how understanding interactions and feedbacks between policies, humans and non-humans can help find viable solutions for increasing individual and collective well-being.

Such a framework could enhance the practice of policy development and implementation. Indeed, placing the focus not on a single policy, but on the relationships between policies and the governance system as a whole, as well as on its social validity could facilitate processes of dialogue and consensus needed in decision-making in conflictive situations. The need for coordination and opportunities for synergies and possible trade-offs could be recognized more easily as well.

\section{State of the art of existing methods to control urban pigeon abundance}

Urban pigeon populations have been controlled in many different metropolises, such as New York (United States), London (United Kingdom), Basel (Switzerland), Barcelona (Spain) and Paris (France), using different methods (review in Haag-Wackernagel, 2002). Reduction of their abundance is based on reducing adult survival and/ or reducing reproductive success, by sterilizing adult females or removing the eggs (Jacquin et al., 2010). In addition, indirect measures include the attempt to lower ecological resources, i.e., food and/or breeding sites (Haag-Wackernagel, 2002). Here we discuss some public control methods of pigeon populations.

\section{Increasing adult mortality by culling methods}

Massive adult culls by shooting or poisoning have been widely used all over Western Europe as a population control method in the past (Sol and Senar, 1992), without any factual decrease in population sizes (Giunchi et al., 2012). Urban pigeons are a long-lived species, with the annual adult survival rate estimated at up to 0.82-0.89 (Récapet et al., 2013), i.e., average adult lifespan ranging from 5 to 9 years. In such a long-lived species, the population growth rate is very sensitive to changes in adult survival (Caswell, 1989). However, because of the high flexibility of pigeon populations in terms of reproduction and dispersal, culled birds are soon replaced by new juveniles and immigrating birds from other areas (Magnino et al., 2009). Moreover, because of its unethical nature, this method fails to attain public acceptance (Fall and Jackson, 2002). Thus, while it might still be employed by some municipalities (Senar et al., 2009), it has been largely abandoned in Central Europe (Haag-Wackernagel, 1995).

\section{Inhibition of reproduction}

Lowering reproductive success has been attempted through sterilizing adult females or removing laid eggs (Jacquin et al., 2010). However, demographic modeling shows that in long-lived species, these measures do not impact the population growth rate significantly, due to the high number of breeding opportunities for adults (Caswell, 1989). Moreover, lowering the number of young pigeons in a particular site encourages the 
immigration of new individuals (Jacob et al., 2014) and/ or the reproduction of other adults, unless the ecological conditions are changed (see next section). Indeed, the implementation of public urban dovecotes in western cities to sterilize or replace most laid eggs (Jacquin et al., 2010; Johnston and Janiga, 1995) has proved to be ineffective in limiting urban pigeon populations (Giunchi et al., 2012). Similarly, control measures based on chemosterilants or other adult reproductive inhibitors have also showed relatively low success (Baldaccini et al., 2000). Moreover, the dispersion of chemosterilants in the human environment can be questionable (Haag-Wackernagel, 1995) because of their potential ingestion by non-target animals such as pets, as well as children.

\section{Limiting resources - feeding ban}

Together with feral cats or domestic sparrows, urban pigeons are regularly fed by some people, for different personal or cultural reasons (Colon and Lequarré, 2013). These regular feeding practices are often identified as a major factor for pigeon population growth (HaagWackernagel, 1997). Several Western cities have implemented a feeding ban on pigeons and urban birds in general in recent decades, potentially resulting in high fines (over 400 euros in France) [Colon and Lequarré, 2013]. However, except for a study from 1988 for the city of Basel (Haag-Wackernagel, 1995), to date there are no published data arguing that feeding ban has any impact on pigeon numbers (Buijs and Van Wijnen, 2001). For instance, the relative importance of food from regular feeding practices compared to the total food available to pigeons in cities remains unknown. Moreover, in an analogous history of city colonization by the hooded crows Corvus corone in Finland, Vuorisalo et al. (2003) argue that the importance of food availability for crow population growth was most likely overestimated in previous research. Crow population growth occurred simultaneously with a decrease in urban food resources due to the improvement of sanitary conditions and the incineration of food waste. As for pigeons, these can fly long distances and can forage in farmland around cities (Rose et al., 2006). This strategy can strongly influence the population size in towns (Hetmański et al., 2011), with different effects in different cities: the proportion of the pigeon population relying on food from outside of the cities can be quite low (6\% in Basel, Switzerland) (Rose et al., 2006), or on the contrary very high ( $46 \%$ in Milan) (Sacchi et al., 2002). Soldatini et al. (2006) further reported variability in pigeons' foraging techniques inside or outside the city throughout the year, depending on the distribution and availability of food resources. This suggests that a feeding ban does not guarantee any limitation in pigeon numbers, as they can flexibly switch to other foraging sources.

\section{Limiting resources - city planning and architecture}

Wild rock doves have historically bred on cliffs in colonies (Baldaccini et al., 2000). Due to this evolutionary origin, urban pigeons look for vertical and rough surfaces for breeding. The architecture of some old buildings thus provides an important supply of nesting opportunities (Sacchi et al., 2002; Ragni et al., 1996). This resource can be artificially regulated, for instance through the obstruction of nesting-suitable slits in buildings. Obstruction of nesting sites was highly effective in Perugia (Italy), with a reduction of $23 \%$ of the city's pigeon population in one year (Ragni et al., 1996). However, except for train stations, airports, historical buildings, and midtown areas, this strategy is not systematically carried out in large cities (Giunchi et al., 2012). Moreover, this measure may also come up against existing legal prescriptions on the built environment, as in the case of legal restrictions in historic monuments in France for instance ${ }^{2}$.

Several different public policy approaches have thus already been tried to reduce pigeon numbers. However, despite high costs (Zucconi et al., 2003; HaagWackernagel, 1995), these controlling measures have never been successful in decreasing the size of pigeon populations (Johnston and Janiga, 1995). In addition to the causes described above, the geographical scale at which these methods are implemented explains their low success. A recent genetic study (Jacob et al., 2014) confirmed that urban pigeons can disperse within a larger geographical area than a single policy unit (Paris city). To be efficient, regulation measures must therefore be implemented simultaneously by all the neighboring cities in the whole urbanized area. Yet, so far, public measures on pigeon regulation have always been decided and implemented independently at the city scale, i.e., always at a smaller scale than the actual pigeon dispersal and colonization range. Based on these considerations, and because we wanted to discuss feasible management solutions, we considered in our analysis that controlling the number of pigeons is not possible.

\section{A new framework to explore pigeon governance in cities}

We used the "social perception" (P) of pigeons as the core of our framework. We further defined two biological variables that may interfere with this core: the aggregation $(\mathrm{A})$, and the health $(\mathrm{H})$ of pigeons.

\footnotetext{
${ }^{2}$ Law on the protection of historic monuments, 31 December 1913; See Article L. 621-1 du Code du patrimoine, www. legifrance.gouv.fr/affichCodeArticle.do?cidTexte=LEGITEX T000006074236\&idArticle $=$ LEGIARTI000006845800\&date Texte $=29990101 \&$ categorieLien $=$ cid.
} 


\section{Why aggregation (A)?}

Historically in France, the first complaints related to feral pigeons appeared when pigeons became abundant and visible in cities, in the period between the two World Wars (Skandrani et al., 2014). Like their ancestors the wild rock doves, urban pigeons behave as a social species (Baldaccini et al., 2000), as evidenced by their foraging behavior (Soldatini et al., 2006; Lefebvre and Giraldeau, 1984). However, contrary to granivorous rock doves (Hoyo et al., 2005), feral pigeons are much more opportunistic and omnivorous in cities, where they typically forage on the ground with a very wide feeding range (from seeds to refuse). When the quantity and location of food are unpredictable, urban pigeon flocks tend to be bigger (Lefebvre and Giraldeau, 1984). In cities, urban pigeons are mainly present on the ground, and do not hesitate to roam beyond urban parks and use sidewalks. Their flight distance (i.e., the distance at which the birds take flight when a human approaches) is quite small compared to those in other bird species (approximately $1.8 \mathrm{~m}$ on average according to MNHN pigeon program [See note 1.]); they therefore live close to pedestrians.

\section{Why pigeon health $(\mathrm{H})$ ?}

Most complaints about pigeons refer to their supposed sanitary state and on the threat of human contamination. However, repeated scientific studies have asserted the very low potential health hazards of pigeons and the very low transmission risk to humans (Gasparini et al., 2011; Haag-Wackernagel and Moch, 2004). In addition, pigeons do not carry diseases that are not also carried by other urban birds (Jerolmack, 2008). However, the visible sanitary state of pigeons could be decisive in determining people's emotional apprehensions linked to aesthetic features (Stokes, 2007). Pigeon health depends on different variables, both environmental and intrinsic: the quantity of pollutants present in pigeon feathers may depend on the local pollution of the environment (Frantz et al., 2012; Nam et al., 2004); the prevalence of haemosporidian parasites (Haemoproteus spp. and Plasmodium spp.) in pigeons depends both on the pigeon morphs and the urbanization rate (Jacquin et al., 2013); and large pigeon gatherings impact pigeon health (Haag-Wackernagel, 2002).

In addition to these two biological variables $\mathrm{A}$ and $\mathrm{H}$, we considered five types of public policies that may affect the level of social perception and/or the level of A and $\mathrm{H}$. Three of these public policies are specific to pigeons: public dovecotes (PD), a feeding ban (FB), and public communication regarding pigeons (PC). The two others are more general: city planning $(\mathrm{CP})$, and public cleanliness $(\mathrm{Cl})$. In brief, our framework proposes

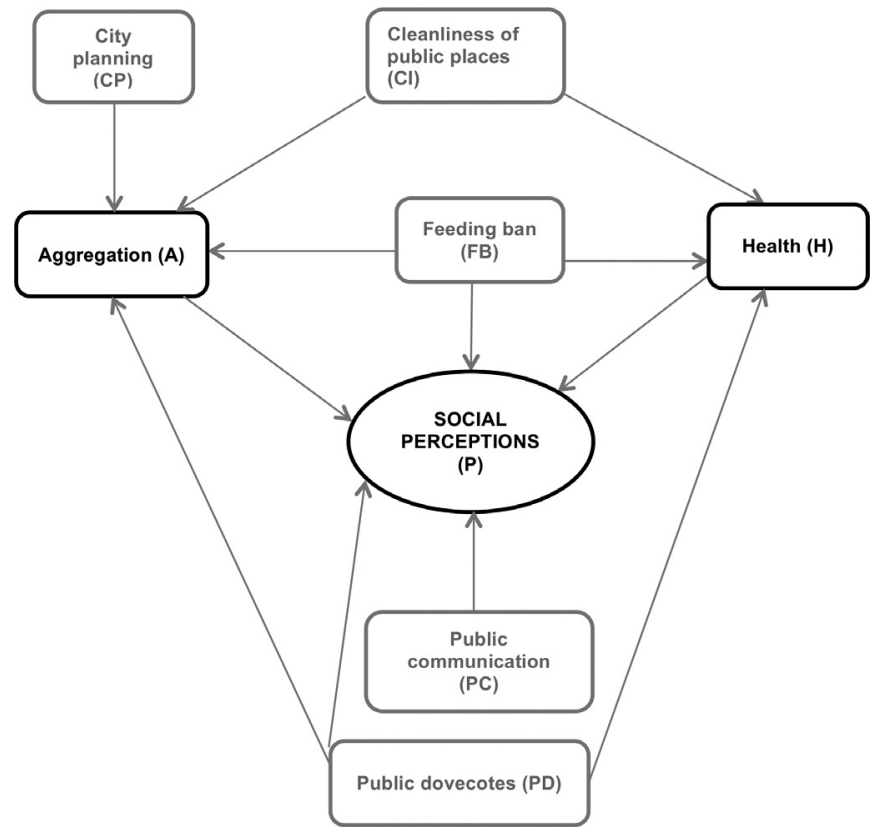

Fig. 1. Framework for renewed urban pigeon governance (copyright by Z. Skandrani, M. Desquilbet, A.-C. Prévot). Public policies are in grey; biological variables and main core are in black.

therefore to link the social perception of pigeons to the aggregation and health of pigeons, and to the three public policies that are specific to pigeons, that is public dovecotes, the presence or absence of a feeding ban, and public communication on pigeons. City planning and public cleanliness impact one or several of these variables (Fig. 1).

\section{Aggregation of urban pigeons in residential settings}

Several public policies are correlated with pigeon aggregations, as detailed below.

\section{Cleanliness of public places (Cl)}

Pigeon numbers in a local area (i.e., aggregation) have been found to be correlated with the local quantity of organic waste produced in the city (Buijs and Van Wijnen, 2001). Indeed, urban pigeons feed on organic waste (Jokimäki and Suhonen, 1998) and concentrate in places where food is readily available (MNHN pigeon program). When ground spaces (sidewalks, streets, parks, etc.) are not cleaned, the availability of organic waste is higher, providing feeding resources for urban pigeons. Cleanliness of public places in a city may thus be negatively correlated with local concentrations of pigeons. 


\section{Feeding ban (FB)}

This public policy may have some unintended consequences by favoring gatherings of pigeons. Indeed, besides the ban, many people continue to feed pigeons, but they are constrained to act fast and secretly. As a result, they feed pigeons early in the morning or late in the evening, and deposit large amounts of grain at once, instead of small quantities in many places (Colon and Lequarré, 2013). By doing this, they may encourage aggregations of pigeons.

\section{Public dovecotes (PD)}

Public dovecotes could be a way to displace pigeon gatherings away from people's living areas or highly frequented spots. Indeed, a study by Dehay (2008) highlighted a very low dispersal of pigeons around dovecotes to which they are faithful in Paris (a few hundred meters), and pigeons have been found to be more highly philopatric towards their breeding sites (Hetmański, 2007).

\section{City planning and architecture $(C P)$}

Pigeons typically breed in social groups on vertical surfaces, which are reminiscent of the natural cliffs were their wild ancestors used to breed (Johnston and Janiga, 1995). Depending on architectural designs, built infrastructures therefore offer good opportunities for pigeons to land and concentrate. Different deterring systems already exist to discourage pigeons to land (HaagWackernagel, 2000); these methods are efficient at a very local scale, to protect one given infrastructure. However, in this circumstance, pigeons move only the least distance possible from the protected structure. In our framework, we therefore propose that the aggregation of pigeon populations depends on the three public policies, as well as on city planning measures (Fig. 1).

\section{Health of urban pigeons}

Several public policies may impact pigeon health, as described below.

\section{Public dovecotes (PD)}

Public dovecotes may impact the sanitary state of pigeons by providing them with more hygienic nesting sites and better or more adequate food (Magnino et al., 2009). In addition, the presence of food inside the dovecotes may limit pigeon foraging on the ground and lower their risk of injury. This is not necessarily the case, however: a study by Gasparini et al. (2011) found that the excretion level of Chlamydiacae did not significantly differ between pigeons captured in a dovecote and pigeons captured on the street.

\section{Cleanliness of public places (Cl)}

In some large cities such as Paris (France), a variable proportion of pigeons show foot mutilations. A preliminary study showed that the levels of foot mutilations of individual pigeons (atrophied claws, stumps) are correlated with the density of inhabitants in the neighborhood (MNHN pigeon program). This result is reinforced by direct observations of pigeons injured by hairs or strings wrapped around the feet when ringing pigeons during the MNHN pigeon program. These results and observations suggest that pigeon mutilations are at least partly linked with the cleanliness status of the ground.

\section{Feeding ban (FB)}

People who regularly feed pigeons are very much concerned with the physical state of pigeons. In addition to feeding, they often apply care measures for pigeons (by treating atrophied claws and administering antiparasite pills), and contribute in this way to better health conditions for pigeons (Colon and Lequarré, 2013). By reducing the opportunities or time for interacting with pigeons, a feeding ban may thus have the unintended consequence of reducing the health status of those urban pigeons that are fed and protected by people who feed them regularly.

\section{Direct effects on common public social perception of public policies and communication concerning pigeons}

Public policies directly devoted to pigeon regulation also have some direct consequences on the social perception of pigeons. Communication programs have been implemented in many cities to discourage pigeon feeding. In Paris, flyers are displayed in urban parks all over the city, stating that feeding animals is dangerous for both the animals and for humans (because of the concentrating effect of feeding, which is said to encourage pathogen dissemination). Although all the scientific results assert the low potential health hazards of pigeons and their transmission risk to humans (see above), pigeons are therefore still designated by officials and institutions as "nuisances" or "pests" based on epidemiological claims, thus further maintaining public concern about these issues (Jerolmack, 2008). Indeed, the nature of public biodiversity management often has a normative impact on public opinion and social perception (Skandrani et al., 2014). In this context, communication campaigns and legal restrictive regulations on bird feeding are a kind of negative institutional communication that contributes to stigmatizing both pigeons and people who feed them (Colon and Lequarré, 2013). 
These legal norms and communications enhance social tensions among people and in relation to pigeons.

On the other hand, public dovecotes are often considered by pigeon protectors as a "good" public policy, based on pigeon health and care. Therefore, these public dovecotes could anchor positive institutional messages, based on the existence of political commitment to the pigeon issue. In addition, public dovecotes may even convey the impression that the situation is under control. Indeed, in Paris, public dovecotes were first presented as "contraceptive dovecotes", but are now presented as "mediation structures" between pigeons and city dwellers (Lizet and Millet, 2012). Public dovecotes constitute a major tool in pigeon governance, they encourage the birds' spatial distribution away from people, they possibly affect their sanitary conditions, and they most likely have a social impact by acting as a reassuring measure that the pigeon issue is being dealt with.

Moreover, the presence of pigeons in cities may offer some services to city-dwellers. First, by eating our refuse, urban pigeons provide a cleaning service (HaagWackernagel, 1995), which has almost never been quantified and is ignored by both local authorities and city dwellers. Another potential service could also derive from the recovery of pigeon droppings collected in public dovecotes in the form of organic fertilizer or methane gas, as has been done for centuries with domestic pigeons. Finally, pigeons could serve as indicators for environmental biomonitoring (Jacquin et al., 2013; Frantz et al., 2012).

Therefore, rethinking institutional communication on pigeons could help city dwellers reach their own opinion concerning pigeons, balancing their own apprehension with counteracting arguments presenting pigeons as socially useful. Such renewed communication could be more scientifically based. It could for instance lower the sanitary risks posed by pigeons, or present pigeons not only as "scroungers" but also as providers of ecosystem services.

In short, our framework suggests that implementing more public dovecotes and increasing public cleanliness measures would both decrease the aggregation and increase the health of pigeons, while a feeding ban has the opposite consequences. In addition, city planning measures could decrease pigeon aggregation. In return, lower aggregation and better health of pigeons positively affect the social perception of pigeons. Social perception is also positively affected directly by the establishment of public dovecotes, while it is negatively affected by the implementation of feeding bans. Finally, depending on its scope and implementation, public communication regarding pigeons may either enhance or reduce social perception towards them.

\section{Discussion}

We have offered here a novel vision of the relations between urban citizens, local authorities and urban pigeons that combines ecological and sociological data to build a model of integrated governance of pigeons in cities. In this model, we treated human-pigeon coexistence not solely in terms of pigeon population control, but more generally in terms of resilience by reducing public dissatisfaction regarding pigeons. To do this, we considered social perceptions of pigeons as central to the model. Targeting social acceptability of pigeons in our framework of urban pigeon governance, we were able to include an increased number of stakeholders and factors of interest compared with traditional pigeon management models. We also stressed the reciprocal linkages between all these stakeholders: city dwellers (and their wellbeing), local public authorities (and their willingness to decrease complaints and increase voter satisfaction) and urban pigeons (and their ecology). We therefore considered the "pigeon problem" in the entirety of their socioecological system. We believe that by reframing the goal of public actions (i.e., toward social perception rather than pigeon abundance), this framework will help address the "pigeon problem" in its entirety and complexity. In this regard, we propose that the public awareness and perceptions about pigeons could be enhanced by different complementary tools: 1) the reduction of local aggregations through measures that enhance the cleanliness of public places, city planning, and strategically located public dovecotes (away from people), as well as a renewed communication with people who feed pigeons regularly; 2) an overall improvement of pigeon sanitary conditions and resistance to parasites, through more hygienic nesting sites in dovecotes, increased cleanliness of public places and a better reliance on pigeon feeders; and 3) renewed institutional communication relating to pigeons and other explicit indicators of urban biodiversity, tending towards more scientifically sound and complete messages.

Our study demonstrates the importance of considering urban biodiversity issues within the city's broader socioecological system. In the absence of such a holistic approach, political measures may have detrimental side effects and are likely to fail. Consider, for instance, feeding restriction policies, which were developed as a means to contain pigeon numbers. They additionally prevent feeder practices such as caring, which are beneficial in terms of pigeon health issues. They also increase the frequency of covert discharges of large amounts of food, which increases pigeon aggregation. We thus propose to switch to a participative management of urban pigeons, integrating feeders as co-carers instead of adversaries. In this context, public dovecotes could hold a pivotal role. For instance, authorizing the feeding 
of pigeons only close to dovecotes may reduce illegal pigeon feeding elsewhere. By feeding close to dovecotes, regular feeders of pigeons would also contribute to maximizing the dovecotes' efficiency in terms of pigeon aggregation away from people and in terms of pigeon health improvement. This would in turn enhance the public perception of pigeons as controlled and healthy. Such comanagement practices would offer opportunities for communication between city dwellers and feeders on the pigeon issue. They could broaden comprehension and may even create new social links around urban pigeons (Jerolmack, 2013), and contribute to fostering community cohesion (Light, 2000). Rather than feeling threatened by pigeons or uneasy, "[...] participatory engagement can empower communities to work toward positive new trajectories" (Gobster, 2005, p. 268).

More generally, our study highlights the importance of institutional messages when dealing with biodiversity issues. Institutions convey messages to the public in two ways: explicitly, through official communication (poster campaigns, mass media, etc.), and also implicitly through policy measures (current regulations, city planning, etc.). Because they are delivered by public institutions, these explicit/implicit messages orientate people's perceptions and opinion (Flynn and Goldsmith, 1994), whatever the direction: for example, by enhancing people's discomfort with urban biodiversity when implementing stigmatizing legal measures as with pigeons, or on the contrary by playing a mediator role. Such significant consequences of institutional communication in creating opinion should encourage public authorities to use public communication with extreme caution. This is particularly tricky in questions concerning complex interactions between humans and urban biodiversity, when communication often insists only on specific negative components of these relations. However, communication that is not based on consensual and validated scientific data (or, in the absence of consensus, on all scientific data) decreases public confidence towards scientists and public authorities (Bradshaw and Borchers, 2000).

Furthermore, our study highlights the detrimental consequences of stigmatization and fear-based messages (Fritsche et al., 2010). Concerning pigeons, institutional communication focuses on health hazards. Generally speaking, raising public anxieties and using fear-based communication may call the attention of people to the problem (Gobster, 2005). However, these "fear appeals" fail to ensure long-term support and are effective only when their recipients (city dwellers) have the ability to enact change and affect the situation (Witte and Allen, 2000). Playing on people's anxieties may also have several negative social repercussions (Hastings et al., 2004). This may first encourage advocacy groups to thwart control efforts (Williams, 2002), such as pigeon feeders and the consequences of their secret food discharges. These advocacy groups may in turn become stigmatized by dismissive institutional messages even without any scientific evidence of the reality of their negative impact. Finally, this pejorative marking may quickly degenerate into opposing group distinctions, where group membership inspires stereotypes and prejudice towards the out-group, thus favoring social conflicts (Koger and Winter, 2010; Whitley and Kite, 2006). Another negative effect of fear-based communication concerns ethics, as it may negatively affect those groups who are unfamiliar with urban biodiversity - i.e., city dwellers in general (Miller, 2005), children or people already experiencing anxiety about animals (Bixler and Floyd, 1997) - and hence further separate people from positive experiences and interactions with natural elements of the environment (Dunn et al., 2006). Finally, the widespread perception of urban species as a nuisance may influence the way people perceive and experience their urban environment as a threat and foster the current culture of fear in our society (Gobster, 2005). We thus call for positive attitudes challenging most current management policies and communication on urban biodiversity. Amongst these, we suggest new governance practices including all involved stakeholders, together with the inclusion of urban biodiversity upstream in planning and decisionmaking.

In this paper, we propose a new analysis of the social conflict concerning the presence of urban pigeons in contemporary French cities and a mitigation approach that both depart from classical models, which only focus on the distribution and abundance of pigeon populations. We addressed urban pigeon management and control and provided a concrete example of mediation and integrative governance in a social conflict on urban biodiversity, built by focusing on perceptions about pigeons and their social and ecological influence factors. We used a concrete case study to examine how new governance models could mediate social conflicts about urban biodiversity by considering the underlying perceptions of nature and socioecological processes. This illustrates how a holistic vision of the complex system linking ecological, social and public realms in the implementation of political measures and governance models of urban nature allows to propose innovative solutions to solve conflicts between urban biodiversity and civil society.

Through this case study, we propose a new socialecological model of urban thinking: namely that urban biodiversity follows its own rules in spreading in anthropic habitats and develops its own specific characteristics in cities. These ecological and behavioral features further dynamically interact with social, political and economic factors, by both influencing and being influenced by the human environment, and thus produce specific perceptions and representations of nature. Delving deeper into these 
interactions provides better comprehension of where and why biodiversity comes into contradiction with human definitions of landscape and society-nature relations. Accordingly, understanding these interlinked socioecological processes allows to determine the specific ecological aspects to act on, and thus, the specific measures that need undertaking at the sociopolitical level to increase social acceptance. Similarly, acknowledging the multiple levels -i.e., institutional communication, policy making, biodiversity management or control, and situational contextthrough which nature perceptions and society-environment relations are mediated and sometimes contradictorily communicated, may help identify and neutralize further conflict-raising elements. We believe that improving our knowledge on the joint construction of nature/biodiversity/ animal conceptions and nature-society relations could be a powerful tool to build shared visions, collective actions and mitigate resistance on environmental and conservation issues. This approach could be generalized and serve as a guide in the development of new governance frameworks addressing social conflicts about urban biodiversity and that aim at finding sustainable solutions for socioecological coexistence and collective well-being.

Finally, we suggest that in the current trend to reconsider/ renegotiate human relations with biodiversity and bring them toward new, more sustainable directions, it is also necessary to allow and create the conditions for all people to participate in this process by giving them their own, free space of interaction with nature.

\section{References}

Baldaccini N.E., Giunchi D., Mongini E., Ragionieri L., 2000. Foraging flights of wild rock doves (Columba l. livia): a spatio-temporal analysis, Italian Journal of Zoology, 67, 4, 371-377.

Bixler R.D., Floyd M.F., 1997. Nature is scary, disgusting, and uncomfortable, Environment and Behavior, 29, 4, 443-467.

Bradshaw G.A., Borchers J.G., 2000. Uncertainty as information. Narrowing the science-policy gap, Ecology and Society, 4, 1, 7.

Buijs J.A., Van Wijnen J.H., 2001. Survey of feral rock doves (Columba livia) in Amsterdam, a bird-human association, Urban Ecosystems, 5, 4, 235-241.

Buijs A.E., Elands B.H.M., 2013. Does expertise matter? An in-depth understanding of people's structure of thoughts on nature and its management implications, Biological Conservation, 168, 184-191.

Caswell H., 1989. Matrix population models. Construction, analysis and interpretation, Sunderland (MA), Sinauer Associates.

Claeys C., Sirost O., 2010. Proliférantes natures. Introduction, Études rurales, 185, 9-22.

Colon P.-L., Lequarré N., 2013. Le nourrissage des pigeons dans la région parisienne, Ethnologie française, 43, 1, 155-162.
Corral S., Acosta M., 2017. Social sensitivity analysis in conflictive environmental governance: a case of forest planning, Environmental Impact Assessment Review, 65, 54-62.

Dehay C., 2008. Fidélité des pigeons (Columba livia) à un pigeonnier urbain. Mémoire de diplôme EPHE des sciences et vie de la Terre, Paris, École pratique des hautes études.

Dunn R.R., Gavin M.C., Sanchez M.C., Solomon J.N., 2006. The pigeon paradox: dependence of global conservation on urban nature, Conservation Biology, 20, 6, 1814-1816.

Fall M.W., Jackson W.B., 2002. The tools and techniques of wildlife damage management-changing needs: an introduction, International Biodeterioration \& Biodegradation, 49, 2-3, 87-91.

Flynn L.R., Goldsmith E., 1994. Opinion leadership in green consumption: an explanatory study, Journal of Social Behavior and Personality, 9, 3, 543-553.

Frantz A., Pottier M.-A., Karimi B., Corbel H., Aubry E., Haussy C., Gasparini J., Castrec-Rouelle M., 2012. Contrasting levels of heavy metals in the feathers of urban pigeons from close habitats suggest limited movements at a restricted scale, Environmental Pollution, 168, 23-28.

Fritsche I., Jonas E., Niesta Kayser D., Koranyi N., 2010. Existential threat and compliance with pro-environmental norms, Journal of Environmental Psychology, 30, 1, 67-79.

Gasparini J., Erin N., Bertin C., Jacquin L., Vorimore F., Frantz A., Lenouvel P., Laroucau K., 2011. Impact of urban environment and host phenotype on the epidemiology of Chlamydiaceae in feral pigeons (Columba livia), Environmental Microbiology, 13, 12, 3186-3193.

Giunchi D., Albores-Barajas Y.V., Baldaccini N.E., Vanni L., Soldatini C., 2012. Feral pigeons: problems, dynamics and control methods, in Soloneski S., Larramendy M.L. (Eds), Integrated pest management and pest control. Current and future tactics, London, InTechOpen, 215-240, www. intechopen.com/books/integrated-pest-management-andpest-control-current-and-future-tactics/feral-pigeons-prob lems-dynamics-and-control-methods.

Gobster P.H., 2005. Invasive species as ecological threat: is restoration an alternative to fear-based resource management?, Ecological Restoration, 23, 4, 261-270.

Gobster P.H., Nassauer J.I., Daniel T.C., Fry G., 2007. The shared landscape: what does aesthetics have to do with ecology?, Landscape Ecology, 22, 7, 959-972.

Gouabault E., Burton-Jeangros C., 2010. L'ambivalence des relations humain-animal. Une analyse socio-anthropologique du monde contemporain, Sociologie et Sociétés, 42, 1, 299-324.

Griffiths I.H., Poulter D.S., 2000. Feral cats in the city, in Philo C., Wilbert C. (Eds), Animal spaces, beastly places: new geographies of human-animal relations, London/New York, Routledge, 59-72.

Haag-Wackernagel D., 1995. Regulation of the street pigeon in Basel, Wildlife Society Bulletin, 23, 2, 256-260.

Haag-Wackernagel D., 1997. Sociocultural reasons for the pigeon problem, Deutsche Tierärztliche Wochenschrift, $104,2,52-57$. 
Haag-Wackernagel D., 2000. Behavioural responses of the feral pigeon (Columbidae) to deterring systems, Folia Zoologica, 49, 2, 25-39.

Haag-Wackernagel D., 2002. Feral pigeons: management experiences in Europe, in Dinetti M. (Ed.), Specie ornitiche problematiche: biologia e gestiona nelle città e nel territorio, Atti del secondo convegno nazionale sulla fauna urbana, 10 Giugno 2000, Firenze, 25-37.

Haag-Wackernagel D., Moch H., 2004. Health hazards posed by feral pigeons, Journal of Infection, 48, 4, 307-313.

Hastings G., Stead M., Webb J., 2004. Fear appeals in social marketing: strategic and ethical reasons for concern, Psychology and Marketing, 21, 11, 961-986.

Hetmański T., 2007. Dispersion asymmetry within a feral pigeon Columba livia population, Acta Ornithologica, 42, 1, 23-31.

Hetmański T., Bocheński M., Tryjanowski P., Skorka P., 2011. The effect of habitat and number of inhabitants on the population sizes of feral pigeons around towns in Northern Poland, European Journal of Wildlife Research, 57, 3, 421-428.

Hoyo J. del, Elliott A., Christie D. (Eds), 2005. Handbook of the birds of the world. Volume 10, Cuckoo-shrikes to thrushes, Barcelona, Lynx Edicions.

Jacob G., Prévot-Julliard A.-C., Baudry E., 2014. The geographic scale of genetic differentiation in the feral pigeon (Columba livia): implications for management, Biological Invasions, 17, 1, 23-29, doi: 10.1007/ s10530-014-0713-2.

Jacquin L., Cazelles B., Prévot-Julliard A.-C., Leboucher G., Gasparini J., 2010. Reproduction management affects breeding ecology and reproduction costs in feral urban pigeons (Columba livia), Canadian Journal of Zoology, 88, 8, 781-787.

Jacquin L., Récapet C., Prévot-Julliard A.-C., Leboucher G., Lenouvel P., Erin N., Corbel H., Frantz A., Gasparini J., 2013. A potential role for parasites in the maintenance of color polymorphism in urban birds, Oecologia, 173, 3, 1089-1099.

Jerolmack C., 2008. How pigeons became rats: the culturalspatial logic of problem animals, Social Problems, 55, 1, 72-94.

Jerolmack C., 2013. The global pigeon, Chicago, The University of Chicago Press.

Johnston R.F., Janiga M., 1995. Feral pigeons, New York, Oxford University Press.

Jokimäki J., Suhonen J., 1998. Distribution and habitat selection of wintering birds in urban environments, Landscape and Urban Planning, 39, 4, 253-263.

Koger S.M., Winter D.D., 2010. The psychology of environmental problems: psychology for sustainability, New York, Psychology Press.

Kalof L., Amthor R.F., 2010. Cultural representations of problem animals in National Geographic, Études Rurales, $185,1,165-180$.

Latour B., 1993. We have never been modern, Cambridge (MA), Harvard University Press.

Lefebvre L., Giraldeau L.-A., 1984. Daily feeding site use of urban pigeons, Canadian Journal of Zoology, 62, 7, 1425-1428.
Light A., 2000. Restoration, the value of participation, and the risks of professionalization, in Gobster P.H., Hull B. (Eds), Restoring nature: perspectives from the social sciences and humanities, Washington (D.C.), Island Press, 163-181.

Lizet B., Millet J., 2012. Le pigeonnier public, à la croisée des utopies sur le vivant dans la ville, in Lizet B., Millet J. (Eds), Animal certifié conforme. Déchiffrer nos relations avec le vivant, Paris, Dunod/Muséum national d'Histoire naturelle, 185-204.

Louv R., 2008. Last child in the woods. Saving our children from nature-deficit disorder, Chapel Hill, Algonquin Books of Chapell Hill.

Magnino S., Haag-Wackernagel D., Geigenfeind I., Helmecke S., Dovc A., Prukner-Radovcic E., Residbegovic E., Ilieski V., Laroucau K., Donati M., Martinov S., Kaleta E.F., 2009. Chlamydial infections in feral pigeons in Europe: review of data and focus on public health implications, Veterinary Microbiology, 135, 1-2, 54-67.

Maris V., Béchet A., 2010. From adaptive management to adjustive management: a pragmatic account of biodiversity values, Conservation Biology, 24, 4, 966-973.

Mathieu N., Rivault C., Blanc N., Cloarec A., 1997. Le dialogue interdisciplinaire mis à l'épreuve: réflexions à partir d'une recherche sur les blattes urbaines, Nature Sciences Sociétés, 5, 1, 18-30.

McKinney M.L., 2002. Urbanization, biodiversity, and conservation. The impacts of urbanization on native species are poorly studied, but educating a highly urbanized human population about these impacts can greatly improve species conservation in all ecosystems, BioScience, 52, 10, 883-890.

Miller J.R., 2005. Biodiversity conservation and the extinction of experience, Trends in Ecology \& Evolution, 20, 8, 430434.

Minteer B.A., Collins J.P., 2005. Why we need an "ecological ethics", Frontiers in Ecology and the Environment, 3, 6, 332-337.

Møller A.P., 2008. Flight distance of urban birds, predation, and selection for urban life, Behavioral Ecology and Sociobiology, 63, 1, 63-75.

Moscovici S., 2000. Social representations. Explorations in social psychology, Cambridge, Polity Press.

Mugerauer R., 2010. Toward a theory of integrated urban ecology: complementing Pickett et al., Ecology and Society, $15,4,31$.

Nam D.H., Lee D.P., Koo T.H., 2004. Monitoring for lead pollution using feathers of feral pigeons (Columba livia) from Korea, Environmental Monitoring and Assessment, 95, 1-3, 13-22.

Ostrom E., 2009. A general framework for analyzing sustainability of social-ecological systems, Science, 325, 5939, 419-422.

Philo C., Wilbert C., 2000. Animal spaces, beastly places: an introduction, in Philo C., Wilbert C. (Eds), Animal spaces, beastly places: new geographies of human-animal relations, London/New York, Routledge, 1-34. 
Pickett S.T.A., Cadenasso M.L., Grove J.M., Groffman P.M., Band L.E., Boone C.G., Burch W.R., Grimmond S.B., Hom J., Jenkins J.C., Law N.L., Nilon C.H., Pouyat R.V., Szlavecz K., Warren P.S., Wilson M.A., 2008. Beyond urban legends: an emerging framework of urban ecology, as illustrated by the Baltimore ecosystem study, Bioscience, 58, 2, 139-150.

Ragni B., Velatta F., Montefameglio M., 1996. Restrizione dell'habitat per il controllo della popolazione urbana di Columba livia, in Alleva E., Baldaccini N.E., Fortuna P., Mantovani A. (Eds), Atti del convegno "Il controllo delle popolazioni ornitiche sinantropiche (piccioni e storni): problemi e prospettive", 10-11 ottobre 1993, Roma, Istituto superiore di sanità, 106-110.

Récapet C., Dauphin L., Jacquin L., Gasparini J., PrévotJulliard A.-C., 2013. Eumelanin-based colouration reflects local survival of juvenile feral pigeons in an urban pigeon house, Journal of Avian Biology, 44, 6, 583-590.

Rivault C., Mathieu N., Cloarec A., Blanc N., 1993. Les blattes. Un animal de ville à toutes saisons, Les Annales de la recherche urbaine, 61, 33-39.

Robbins P., 2007. Lawn people. How grasses, weeds, and chemicals made us who we are, Philadelphia, Temple University Press.

Rose E., Nagel P., Haag-Wackernagel D., 2006. Spatio-temporal use of the urban habitat by feral pigeons (Columba livia), Behavioral Ecology and Sociobiology, 60, 2, 242-254.

Rosenzweig M.L., 2003. Reconciliation ecology and the future of species diversity, Oryx, 37, 2, 194-205.

Sacchi R., Gentilli A., Razzetti E., Barbieri F., 2002. Effects of building features on density and flock distribution of feral pigeons Columba livia var. domestica in an urban environment, Canadian Journal of Zoology, 80, 1, 48-54.

Senar J.C., Carrillo J., Arroyo L., Montalvo T., Peracho V., 2009. Estima de la abundancia de palomas (Columba livia var.) de la ciudad de Barcelona y valoración de la efectividad del control por eliminación de individuos, Arxius de Miscel-lània Zoològica, 7, 62-71.

Serpell J.A., 2004. Factors influencing human attitudes to animals and their welfare, Animal Welfare, 13, supplementary issue, Proceedings of the UFAW International Symposium "Science in the service of animal welfare", 145-151.
Skandrani Z., Lepetz S., Prévot-Julliard A.-C., 2014. Nuisance species: beyond the ecological perspective, Ecological Processes, 3, 1, 1-12.

Soga M., Gaston K.J., 2016. Extinction of experience: the loss of human-nature interactions, Frontiers in Ecology and Environment, 14, 2, 94-101.

Sol D., Senar J.C., 1992. Comparison between two censuses of Feral Pigeon Columba livia var. from Barcelona: an evaluation of seven years of control by killing, Butlleti del Grup Català d'Anellament, 9, 29-32.

Soldatini C., Mainardi D., Baldaccini N.E., Giunchi D., 2006. A temporal analysis of the foraging flights of feral pigeons (Columba livia f. domestica) from three Italian cities, Italian Journal of Zoology, 73, 1, 83-92.

Stokes D.L., 2007. Things we like: human preferences among similar organisms and implications for conservation, Human Ecology, 35, 3, 361-369.

Visseren-Hamakers I.J., 2015. Integrative environmental governance: enhancing governance in the era of synergies, Current Opinion in Environmental Sustainability, 14, 136-143.

Vuorisalo T., Lehikoinen E., Lahtinen R., 2001. History of domestic and feral pigeons (Columba livia) in Finland before 1900 A.D., Ornis Fennica, 78, 119-126.

Vuorisalo T., Andersson H., Hugg T., Lahtinen R., Laaksonen H., Lehikoinen E., 2003. Urban development from an avian perspective: causes of hooded crow (Corvus corone cornix) urbanisation in two Finnish cities, Landscape and Urban Planning, 62, 2, 69-87.

Whitley B.E., Kite M.E., 2006. The psychology of prejudice and discrimination, Belmont (CA), Thomson Wadsworth.

Williams T., 2002. America's largest weed. Eucalyptus has its defenders, but today, 150 years after these "wonder trees" were first brought to coastal California, their dark side is coming to light, Audubon, 104, 1, 24-31.

Witte K., Allen M., 2000. A meta-analysis of fear appeals: implications for effective public health campaigns, Health Education \& Behavior, 27, 5, 591-615.

Zucconi S., Galavotti S., Deserti R., 2003. I colombi in ambiente urbano, Disinfestazione, 9-21.

Cite this article as: Skandrani Z., Desquilbet M., Prévot A.-C., 2018. A renewed framework for urban biodiversity governance: urban pigeons as a case-study. Nat. Sci. Soc. 26, 3, 280-290. 